\title{
The use of rocks to improve family agriculture in Brazil
}

\author{
SUZI H. THEODORO ${ }^{1}$ and OTHON H. LEONARDOS ${ }^{2}$ \\ ${ }^{1}$ Universidade de Brasília, Centro de Estudos Avançados Multidisciplinares, Núcleo de Estudos Agrários \\ Campus Darcy Ribeiro, Edifício Multiuso I, Bloco B, $1^{\circ}$ Andar, sala B1-50 \\ 70910-900 Brasília, DF, Brasil \\ ${ }^{2}$ Universidade de Brasília, Centro de Desenvolvimento Sustentável, SAS Quadra 05, Bloco H, sala 200 \\ 70070-914, Brasília, DF, Brasil
}

Manuscript received on September 29, 2005; accepted for publication on March 13, 2006; contributed by OTHON H. LEONARDOS*

\begin{abstract}
During the second half of the $20^{\text {th }}$ century, the introduction of new chemical agriculture technologies brought about a revolution in food production, but this has also cause deep deterioration in our relationships with the natural environment. In developing tropical countries, record yields were accompanied by rural exodus, widespread deforestation and loss of topsoil. The stonemeal research described herein is an alternative to such practices as it is an environmental friendly and socially responsible technology based on soil rejuvenation and conservation by means of the addition of natural rock powders that are rich in phosphorous, calcium, magnesium, potassium and micronutrients. The research adopted an inter-disciplinary approach and was conducted among small farmers of a rural community located in the state of Minas Gerais, Brazil. The major goal was to demonstrate that there is a harmless cheap and simple alternative to fertilizing degraded or impoverished soils, which allow farmers to sustain high productivity and to remain on their plots of land. Results have confirmed the economic, environmental and productive feasibility and advantage of the stonemeal technique for corn, rise, manioc, sugar cane and horticultural species, when compared to the use of chemical fertilizers. The fertilization of the soil with rocks, allows the understanding of the natural processes, which maintain production levels while building a sustainable fertile soil.
\end{abstract}

Key words: stonemeal, nutrients, small farmers.

\section{INTRODUCTION}

Many of the problems of tropical agriculture originate in the nature of soils. Tropical soils commonly have inherently low fertilities. They have been exposed to long periods of weathering, which results in highly depleted soils with low organic matter, low cation exchange capacities and overall low inherent fertility (van Straaten 2002). This kind of situation

\footnotetext{
*Member Academia Brasileira de Ciências Correspondence to: Suzi Huff Theodoro

E-mail: suzitheodoro@unb.br
}

which is common with Brazilian' soils contributes to the low sustainability of agricultural practices in Brazil. This is, however, a highly complex issue, due to influence of multiple environmental, social and cultural constraints and bias. Its complexity is further enhanced by the varying economic and political local situations under which the agricultural productive system is organized. Record yields that grain crop, which sustain the economy and growth of the country's modern agriculture, causing unacceptable environment devastation and income in- 
equalities, triggering social exclusion. As capital is accumulated among the richest high-tech agribusiness entrepreneurs, the ecological responsible traditional family farmer is vanishing. It is the case where more grain yields means less forests and more hunger, and therefore, a major world political and scientific concern has already been recognized at the UN sponsored Agenda 211992.

As present large-scale chemical agriculture departs from natural resources conservation practices and it is not promoting social inclusion, there has been growing criticism upon its continuous practice. While agriculture land use has increased $76 \%$ in 27 years the use of toxic agrochemicals has increased $276 \%$ (S.M.C.H. Theodoro, unpublished data). Campanhola 1995 shows that nutrient loss in Brazil has an average direct cost of 242 million dollars per year, and that indirect annual costs related to the use of toxic agrochemicals is over a dozen billion dollars, including public health damages, water and soil contamination, pest resistance etc. This sort of data well illustrates the quest for alternative agriculture, in particular for family farmers whose production strategy is based on land resources rather than on market offers.

In traditional family agriculture systems, production acts as a simplified natural ecosystem, where energy is not dispersed in the productive chain. The technological input is small as it is small its productivity. This group of farmers is distant from the formal market, it does not dispose of financial or technological incentives, and consequently, lives on the margin of society. The immediate result of such a process is social and spatial exclusion from the real world.

To reverse such unsustainable scenarios, which threaten, both the ecological and the social/cultural system web of life in which the agriculture is implanted a move towards the adoption of technologies based on agro-ecological sustainable principles is imperative. Towards this goal, we have addressed the problem of (re)mineralizing or rejuvenating nutrient-poor or degraded soils in Agrarian Reform settlements by applying rock fertilizers or the stonemeal technique (the rochagem method) as suggested by Leonardos et al. $(1976,1987)$ and we have compared it to the use of chemical fertilizers or no fertilizer. The rock fertilizer practice is the incorporation of ground rocks to the soil in a similar manner as liming is done, liming being a particular case of rock fertilization. The strategy behind our work was the insertion of family farming on a productive model that would achieve harmony with nature. Improvement in productivity, achievement of long term soil fertility and social-cultural gains would hypothetically help disseminate the practice among family farmers and trigger more sustainable public policies.

Rock fertilizers may also become an advantageous economic and environmental solution for fertilizing Brazilian soils (Leonardos et al. 2000). It does not require concentration processes and chemical attacks; it may be ready for use (as in the present situation) and production costs are minimal (extraction and crushing costs when needed, will not exceed US\$ 10 per ton). When considered an available residue from local quarrying or tailings of mining activities, it may be even given out free.

\section{THE APPROACH: METHODS AND MATERIALS}

Our aim was to evaluate the use of local rocks as fertilizers by family agriculture farmers in the Agrarian Reform settlements, as compared with NPK fertilizers and no fertilizer at all in the context of sustainable development. Based on previous works by Ilchenko and Guimarães 1953, Guimarães 1955, Leonardos et al. 1976, 1987, we selected the Mata da Corda volcanic rocks as the best likely materials to be used as rock fertilizers in such settlements. Their tuffs, lavas and pipes were richer in macro and micro nutrient elements than most rocks, and besides, they have ample distribution (450 sq km) in the Central Plateau of Brazil. They were ultra-potassic ultramafic volcanic rocks of kamafugitic to lamproitic or kimberlitic affinity (Gibson et al. 1995). Large olivine and phlogopite crystals in a matrix of olivine, diopside, phlogopite, 
perovskite, richterite, kalsilite, apatite, mellilite and zeolites formed their mineralogy. In general, they were silica deficient rocks $\left(\mathrm{SiO}_{2}: 29,91 \%\right.$ to $36,11 \%$ ) with a high $\mathrm{K} / \mathrm{Na}(>3)$ ratio and high magnesium, potassium and phosphorus values, reaching up to $16.8,7.0$ and 5,0 weight \%, respectively (Moraes et al. 1988, Leonardos and Meyer 1991, Gibson et al. 1995). Soils derived from these rocks had supported the largest forest which had once existed in the region: that of "The Mata (forest) da Corda".

Neighboring soils derived from the Bambui aluminous sediments were, in contrast, barren. We also knew that the forest was knocked down to give place to the rich corn belt of Patos de Minas, which extended from Presidente Olegário to beyond Carmo do Paranaíba, at the expenses of the volcanic rock nutrients (Leonardos and Theodoro 1999). All we needed then was to find an appropriate place, where the farmers could experiment and demonstrate themselves the advantages of the rochagem method, viewing the promotion of sustainable agriculture with the use of the Mata da Corda volcanic rocks.

The approach to this was interdisciplinary and complex. Integration of what could be measured and reasoned, and what could be perceived and felt was necessary, as we wanted to go beyond recording productivity, in order to unveil simultaneous chemical, mineralogical, environmental, social, economic, cultural and psychological changes. We avoided controlled artificial experiments whose results family farmers would hardly digest. Instead, we opted to let the farmers conduct the experiments themselves, so they could see, measure and feel results with their own eyes, hearts and pockets.

The community that was selected was INCRA's Fruta D'Antas Settlement in the state of Minas Gerais, then ten years old. The community was formed of about 1,000 people, distributed among 220 families of small agriculture workers in areas of about 40 ha (Theodoro et al. 2000a). Installed $50 \mathrm{~km}$ east of João Pinheiro, on the infertile sandy to clayish soils derived from the Bambui sediments, Fruta D'Anta was the closest $(200 \mathrm{~km}$ eastward) INCRA settlement to the Mata da Corda rock source.

A few months before installing the experiment, we held two full-day workshops on how we could best relate to nature and keep our land producing for the next generations. We also discussed the potentiality of using local rocks as fertilizers. From one hundred participants, who actively participated in the workshop representing the two hundred family groups, we later selected eight pilot areas. These belonged to volunteers that appeared more responsible, and from a wider variety of soil situations (soil chemistry, relief, water availability etc). One hundred tons of weathered tuff and lava were then placed and made available at the central area of Fruta D'Anta. The materials were selected from friable rock materials, where chemical analysis was previously carried out (see Table I). The selected materials were weathered rocks, which had larger $\mathrm{P}_{2} \mathrm{O}_{5}$ contents $(>2.0 \mathrm{wt} \%)$ and came from among the areas where landowners had granted permission to extract them, from closer road cuts and from where mining would only involve filling up the trucks. Mining the material was only possible with the help of the State Road Department (DER-MG).

To the eight pilot area volunteers, we requested that each carried out comparative experimental parcels using a) the rocks that were made available b) the convention NPK treatment they were accustomed and, if they wanted, c) a mixture of the two. We commonly agreed on experimenting seasonal crops like maize, sugar cane, cassava, rice and watermelon, upon rock dosages of 2.5 to 3 ton/ha applied along the plantation grooves, and to keep the size of 0,5 ha for each experimental parcel. Farmers were free to use NPK dosages following the recipes they had used from previous crops, but under the commitment they would carefully record the dosages. In the second year, ten new pilot areas were added; some farmers were advised to use the rock fertilizer, in combination with organic compost made from household garbage and animal manure (Theodoro et al. 2000b). 


\section{TABLE I}

Whole-rock chemistry of Mata da Corda volcanic rocks from road cuts in the Presidente Olegário region. Major element oxides are expressed in weight \%, and minor elements in ppm. Dept. Geoquímica, UnB (Geraldo Boaventura, analyst) (S.M.C.H. Theodoro, unpublished data).

\begin{tabular}{|c|c|c|c|c|c|c|c|c|c|c|c|c|}
\hline Samples & $1 \mathrm{~A}$ & 1B & $2 \mathrm{~A}$ & $3 \mathrm{~A}$ & $3 \mathrm{~B}$ & $4 \mathrm{~A}$ & $5 \mathrm{~A}$ & $6 \mathrm{C}$ & $6 \mathrm{~L}$ & $6 \mathrm{LA}$ & $7 \mathrm{~A}$ & $8 \mathrm{~A}$ \\
\hline$\overline{\mathrm{SiO}_{2}}$ & 33.67 & 30.07 & 34.39 & 29.82 & 30.18 & 30.47 & 29.91 & 31.89 & 36.11 & 32.38 & 35.49 & 32.19 \\
\hline $\mathrm{TiO}_{2}$ & 7.88 & 9.18 & 6.99 & 7.73 & 6.16 & 10.45 & 8.23 & 6.34 & 6.11 & 3.61 & 8.04 & 7.96 \\
\hline $\mathrm{Al}_{2} \mathrm{O}_{3}$ & 7.62 & 8.12 & 8.02 & 5.43 & 6.98 & 7.62 & 9.08 & 4.64 & 5.44 & 4.26 & 7.09 & 7.24 \\
\hline $\mathrm{Fe}_{2} \mathrm{O}_{3}$ & 21.53 & 22.44 & 20.67 & 21.50 & 14.09 & 21.81 & 20.58 & 11.57 & 9.92 & 8.06 & 22.01 & 22.11 \\
\hline $\mathrm{FeO}$ & 1.06 & 0.61 & 0.01 & $<$ & 0.77 & 0.53 & 0.01 & 2.53 & 4.60 & 0.13 & 0.01 & 0.24 \\
\hline $\mathrm{MnO}$ & 0.25 & 0.26 & 0.45 & 0.29 & 0.20 & 0.30 & 0.30 & 0.18 & 0.18 & 0.17 & 0.22 & 0.26 \\
\hline $\mathrm{MgO}$ & 5.16 & 4.59 & 5.11 & 11.22 & 10.22 & 4.46 & 6.61 & 15.11 & 16.83 & 14.72 & 4.41 & 4.66 \\
\hline $\mathrm{CaO}$ & 0.61 & 3.86 & 1.48 & 5.57 & 7.16 & 2.65 & 3.61 & 10.25 & 11.28 & 12.21 & 1.32 & 2.96 \\
\hline $\mathrm{Na}_{2} \mathrm{O}$ & $<0.5$ & $<0.5$ & $<0.5$ & $<0.5$ & $<0.5$ & $<0.5$ & $<0.5$ & $<0.5$ & $<0.5$ & $<0.5$ & $<0.5$ & $<0.5$ \\
\hline $\mathrm{K}_{2} \mathrm{O}$ & 1.64 & 1.26 & 3.30 & 1.19 & 2.13 & 1.49 & 2.52 & 1.24 & 1.07 & 1.36 & 1.09 & 1.12 \\
\hline $\mathrm{P}_{2} \mathrm{O}_{5}$ & 0.49 & 3.06 & 1.68 & 1.57 & 2.37 & 2.43 & 3.31 & 2.21 & 0.40 & 2.21 & 1.98 & 2.47 \\
\hline $\mathrm{IL}$ & 19.38 & 17.32 & 17.87 & 15.30 & 19.47 & 17.74 & 16.07 & 13.54 & 7.15 & 21.30 & 18.67 & 19.36 \\
\hline TOTAL & 99.29 & 100.77 & 99.96 & 99.92 & 99.73 & 99.95 & 99.96 & 99.90 & 99.15 & 100.61 & 100.33 & 100.57 \\
\hline $\mathrm{V}$ & 271 & 448 & 258 & 335 & 154 & 554 & 197 & 214 & 297 & 135 & 398 & 293 \\
\hline $\mathrm{Nb}$ & 322 & 340 & 263 & 266 & 244 & 390 & 313 & 235 & 210 & 175 & 327 & 322 \\
\hline $\mathrm{Sr}$ & 133 & 698 & 579 & 1200 & 1073 & 892 & 1286 & 1020 & 1689 & 1244 & 1409 & 550 \\
\hline $\mathrm{Y}$ & 190 & 53 & 52 & 42 & 42 & 78 & 71 & 37 & 32 & 30 & 144 & 119 \\
\hline $\mathrm{Ni}$ & 513 & 541 & 466 & 485 & 353 & 570 & 738 & 262 & 377 & 260 & 640 & 687 \\
\hline $\mathrm{Zr}$ & 1188 & 1350 & 1210 & 920 & 1100 & 1470 & 1500 & 975 & 891 & 766 & 1280 & 1300 \\
\hline $\mathrm{Cu}$ & 226 & 227 & 205 & 117 & 150 & 254 & 323 & 115 & 102 & 93 & 299 & 236 \\
\hline $\mathrm{Be}$ & 6 & 7 & 8 & 5 & 6 & 11 & 9 & 5 & 4 & 4 & 14 & 8 \\
\hline $\mathrm{Cr}$ & 368 & 280 & 286 & 1503 & 290 & 226 & 145 & 5400 & 681 & 160 & 300 & 460 \\
\hline $\mathrm{Ba}$ & 587 & 1000 & 5861 & 852 & 1253 & 2450 & 5189 & 1264 & 4006 & 1062 & 2632 & 658 \\
\hline Co & 193 & 180 & 201 & 186 & 124 & 326 & 180 & 133 & 150 & 99 & 274 & 213 \\
\hline $\mathrm{Zn}$ & 211 & 194 & 195 & 157 & 118 & 328 & 264 & 124 & 109 & 86 & 276 & 286 \\
\hline
\end{tabular}

The experiments were visited in 2-3 month intervals, when we recorded the farmers reported measurements, findings and failures. Soil sampling follow-ups, with the purpose of recording chemical and mineralogical rates, were made at yearly trips. X-ray diffraction, total chemistry and agronomical soil fertility analysis of the sampled soils were respectively carried out in mineralogical, geochemistry and soil fertility laboratories; they helped us explain the natural improvement of soil fertility in chemical, mineralogical and agronomical terms. On these trips, notes and photographs of the experiments were taken in various stages of plant development, and most importantly, we conducted free interviews with the farmers on the experiment. These interviews were taped and video recorded. Beside rational and intuitive assessments and reflections about the experiments, farmers let out their memories and dreams when observing native rocks at work: feeding plants and themselves.

\section{RESULTS}

\section{SElecting ApPropriate MATERials}

In addition to the fresh rock chemical data available from previous literature, a new whole-rock chemical data for the weathered materials, which were ready for use and easy to mine, were carried out. Results were given on Table I. From that and from Table II, sample 3B was selected as the best material to be used on the grounds of its higher $\mathrm{P}_{2} \mathrm{O}_{5}$ (2.37 wt\%), $\mathrm{MgO}\left(10.22\right.$ ) and $\mathrm{K}_{2} \mathrm{O}$ (2.13) con- 
TABLE II

Soil fertility analysis of Mata da Corda rock samples (S.M.C.H. Theodoro, unpublished data).

\begin{tabular}{c|c|c|c|c|c|c}
\hline Sample & $\begin{array}{c}\mathrm{pH} \\
(1: 2,5)\end{array}$ & $\begin{array}{c}\mathrm{Al} \\
\mathrm{meq} / 100 \mathrm{cc}\end{array}$ & $\begin{array}{c}\mathrm{Ca}+\mathrm{Mg} \\
\mathrm{meq} / 100 \mathrm{cc}\end{array}$ & $\begin{array}{c}\mathrm{P}(\mathrm{mg} / \mathrm{l}) \\
\mathrm{ppm}\end{array}$ & $\begin{array}{c}\mathrm{K}(\mathrm{mg} / \mathrm{l}) \\
\mathrm{ppm}\end{array}$ & $\begin{array}{c}\text { Sat. } \\
\mathrm{Al}(\%)\end{array}$ \\
\hline 1 A & 4.71 & 4.35 & 38.9 & 140 & 206 & 10 \\
\hline 1 B & 5.00 & 2.00 & 48.2 & 1215 & 207 & 4 \\
\hline 2 A & 5.01 & 0.90 & 40.7 & 2285 & 161 & 2 \\
\hline 3 A & 6.10 & 0.05 & 72.9 & 1892 & 158 & 0 \\
\hline 3 B & $\mathbf{5 . 9 7}$ & $\mathbf{0 . 0 5}$ & $\mathbf{5 7 . 9}$ & $\mathbf{3 0 3 8}$ & $\mathbf{1 8 8}$ & $\mathbf{0}$ \\
\hline 4 A & 4.75 & 1.70 & 49.7 & 3391 & 167 & 3 \\
\hline 5 A & 5.00 & 1.45 & 37.9 & 1394 & 201 & 4 \\
\hline 7 A & 4.65 & 3.90 & 45.4 & 1599 & 199 & 8 \\
\hline 8 A & 5.02 & 0.90 & 60.4 & 1948 & 308 & 1 \\
\hline
\end{tabular}

tents, lower $\mathrm{Al}_{2} \mathrm{O}_{3}(6.98)$ and $\mathrm{Fe}_{2} \mathrm{O}_{3}$ (14.09) and high ignition loss $(19.47 \mathrm{wt} \%)$ which indicates high montmorillonite /nontronite /vermiculite contents, as has been demonstrate in the X-ray diffratograms given in S.M.C.H. Theodoro, unpublished data, p. 166.

The same samples that had undergone full dissolution to provide the whole chemistry analysis as displayed on Table I (as used by geochemists), underwent partial sulfuric acid dissolution to produce the partial soil analysis of Table II, reflecting fertility potential (as used by soil scientists). It is interesting to note that both sets of analysis, point out towards sample $3 \mathrm{~B}$ as the best option for being used as rock fertilizer.

In Table II, the 3B sample is chosen for its high $\mathrm{pH}, \mathrm{Ca}+\mathrm{Mg}, \mathrm{P}$ and $\mathrm{K}$ contents and low $\mathrm{Al}$. It also clearly shows that analyzing a rock powder as a soil material could shorten the way to assess a given rock fertility potential. The data helps reassure soil scientists that (powdered) rock is indeed soluble.

\section{RESULTS OF EXPERIMENTS}

A complete five-year-old soil fertility follow-up analysis was limited to soil samples from areas 19, 21, 79 and 129. Results are presented in Table III. In the other areas experiments, the follow-up was limited and discontinued, due to a variety of reasons such as flooding, drying plants in NPK parcels, loss of productivity and dosage records, lack of systematic observation and uncontrolled use of pesticide. In all situations there was substantial (area 19, 129) or dramatic (areas 21, 79) increase in $\mathrm{pH}, \mathrm{Ca}+\mathrm{Mg}$, $\mathrm{P}$ and $\mathrm{K}$ values after the first crop and a tendency for stabilizing or gradually decreasing after the second crop. Even after 5 years, all values remained higher (most by one order of magnitude) than before the rock was introduced. The high aluminum toxicity became and remained nihil right in the first crop.

As a way of making a comparison, a fertility analysis was conducted in the part of the soil manured with chemical fertilizer (area 79). The results show that all the load of chemical insume applied NPK (4-30-16, simple super phosphate and ammonia sulfate) was practically depleted. The analysis revealed a $\mathrm{pH}$ of 4,8 , high aluminium $(3,40 \mathrm{meq} / 100 \mathrm{cc})$, calcium plus magnesium $(2,40 \mathrm{meq} / 100 \mathrm{cc})$, phosphorous $(7,0 \mathrm{ppm})$ and potassium (33 $\mathrm{ppm})$.

Productivity data, employed dosages and remarks about the experiments for maize, sugar cane, manioc and rice are summarized in Table IV. Several items stand out in the results: (a) the productivity was the same or higher (up to $40 \%$ ) than for 


\section{TABLE III}

Soil fertility analysis of soil samples before and after rock fertilizer application. Source:

(S.M.C.H. Theodoro, unpublished data and Theodoro and Leonardos 2004).

\begin{tabular}{|c|c|c|c|c|c|}
\hline Area & Parameters & Before rock appl. & After 1st crop & After 2nd crop & After 5 years \\
\hline \multirow{6}{*}{19} & $\mathrm{pH}(1: 2.5)$ & 5.20 & 5.90 & 5.6 & 6.5 \\
\hline & $\mathrm{Al}$ (meq/100 cc) & 0.00 & 0.00 & 0.0 & 0.0 \\
\hline & $\mathrm{Ca}+\mathrm{Mg}(\mathrm{meq} / 100 \mathrm{cc})$ & 2.7 & 5.6 & 5.6 & 3.6 \\
\hline & $\mathrm{P}(\mathrm{mg} / \mathrm{l}) \mathrm{ppm}$ & 3 & 40 & 52 & 10 \\
\hline & $\mathrm{K}(\mathrm{mg} / \mathrm{l}) \mathrm{ppm}$ & 9 & 79 & 108 & 17.7 \\
\hline & Sat. Al (\%) & 0.0 & 0.0 & 0,0 & 0.0 \\
\hline \multirow{6}{*}{21} & $\mathrm{pH}(1: 2.5)$ & 3.76 & 6.40 & 5.50 & 4.8 \\
\hline & $\mathrm{Al}$ (meq/100 cc) & 1.75 & 0.00 & 0.00 & 0.0 \\
\hline & $\mathrm{Ca}+\mathrm{Mg}(\mathrm{meq} / 100 \mathrm{cc})$ & 0.5 & 7.2 & 5.8 & 0.5 \\
\hline & $\mathrm{P}(\mathrm{mg} / \mathrm{l}) \mathrm{ppm}$ & 3 & 33.9 & 271 & 25 \\
\hline & $\mathrm{K}(\mathrm{mg} / \mathrm{l}) \mathrm{ppm}$ & 31 & 85 & 57 & 15 \\
\hline & Sat. Al (\%) & 75 & 0.0 & 0.0 & 1.2 \\
\hline \multirow{6}{*}{79} & $\mathrm{pH}(1: 2.5)$ & 3.60 & 7.30 & 7.40 & 6.5 \\
\hline & $\mathrm{Al}(\mathrm{meq} / 100 \mathrm{cc})$ & 3.25 & 0.00 & 0.00 & 0.0 \\
\hline & $\mathrm{Ca}+\mathrm{Mg}(\mathrm{meq} / 100 \mathrm{cc})$ & 0.4 & 10.3 & 10.6 & 4.2 \\
\hline & $\mathrm{P}(\mathrm{mg} / \mathrm{l}) \mathrm{ppm}$ & 0 & 11 & 21 & 8.2 \\
\hline & $\mathrm{K}(\mathrm{mg} / \mathrm{l}) \mathrm{ppm}$ & 15 & 132 & 81 & 15 \\
\hline & Sat. $\mathrm{Al}(\%)$ & 88 & 0.0 & 0.0 & 0.0 \\
\hline \multirow{6}{*}{129} & $\mathrm{pH}(1: 2.5)$ & 4.36 & 5.50 & 5.50 & 4.7 \\
\hline & $\mathrm{Al}(\mathrm{meq} / 100 \mathrm{cc})$ & 1.00 & 0.00 & 0.00 & 0.0 \\
\hline & $\mathrm{Ca}+\mathrm{Mg}(\mathrm{meq} / 100 \mathrm{cc})$ & 0.7 & 3.9 & 3.7 & 2.2 \\
\hline & $\mathrm{P}(\mathrm{mg} / \mathrm{l}) \mathrm{ppm}$ & 9 & 77 & 47 & 35.5 \\
\hline & $\mathrm{K}(\mathrm{mg} / \mathrm{l}) \mathrm{ppm}$ & 93 & 167 & 93 & 19 \\
\hline & Sat. Al (\%) & 52 & 0.0 & 0.0 & 0.0 \\
\hline
\end{tabular}

the plots in which chemical fertilizers were applied; (b) long-term cultures (sugar cane and manioc) achieved better productivity; (c) corn and rice also improved their yields, matching the levels of areas treated with agro-chemicals; (d) the additional use of organic compost was advantageous, showing that the combination of organic and rock fertilization may fulfill most if not all nutrient requirements for macro and micro-nutrients; (e) humidity was higher around plants receiving the rock powder treatment, showing that the clays contained in the material had strong ability to retain water; (f) plants treated with rock powder displayed exuberant green leaves (in the case of manioc and sugar cane); ( $\mathrm{g}$ ) roots of rock-treated plants were more abundant and developed than the plants that went through conventional treatment $(\mathrm{h})$ costs of applying rock powder were much lower $(<60 \%)$, due to long term fertility effect. These results confirmed the economic and financial potential of the employed rock fertilizers leading to its immediate acceptance by small farmers.

The experiments have also triggered farmers' awareness of other complex and interrelated ecological, social, cultural and human behavior variables, which favor sustainable agriculture and therefore, improve natural and human habitat life quality. Soon after experiments were started, some changes could be observed: a cooperative was formed and engaged on improving cattle management, dairy products 


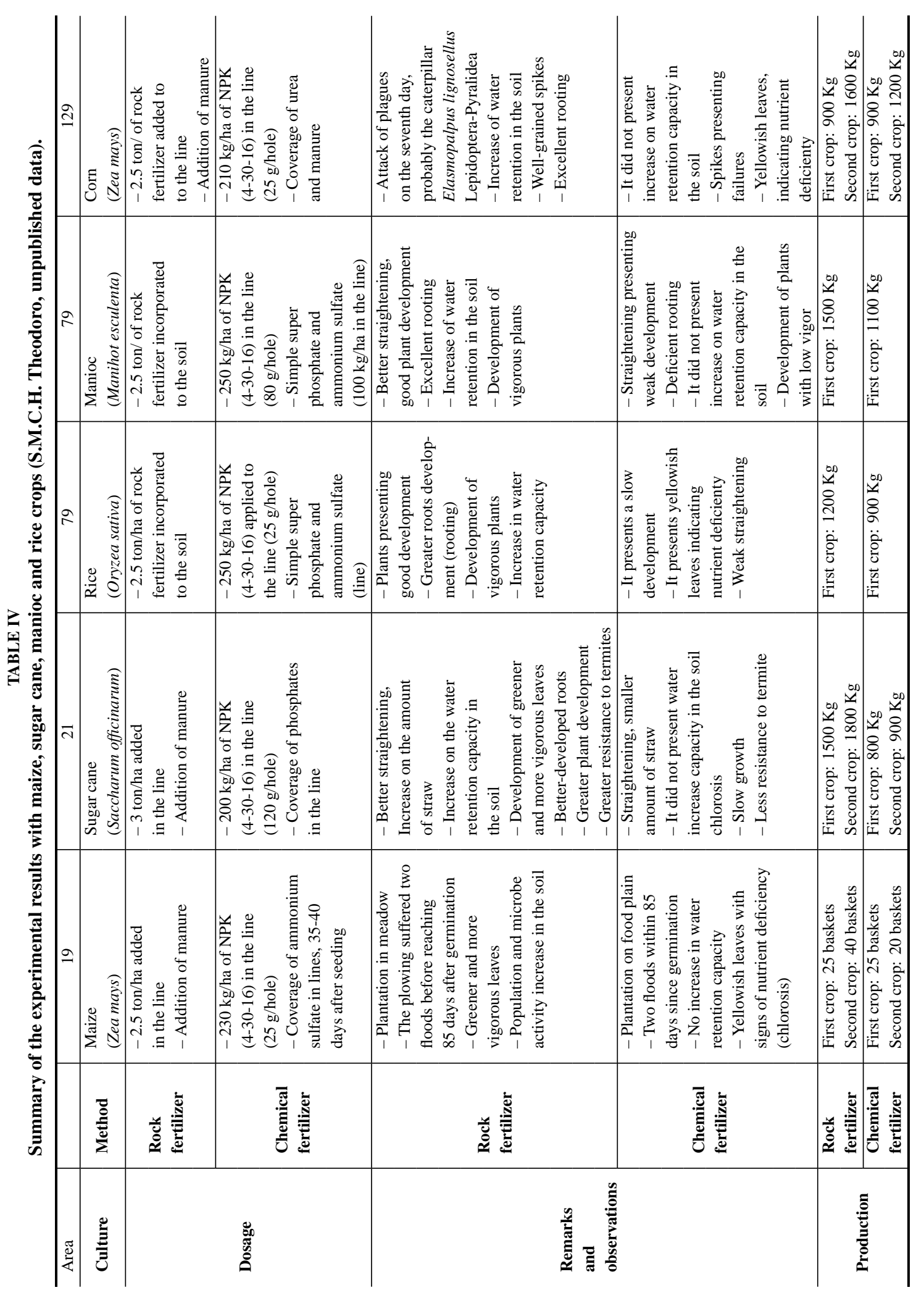


and other local food products. A supermarket was built and through responsible management prices of sold merchandise dropped considerably, as purchase was done directly from retailers. Local products such as vegetables, meat, dairy products, home made sweets and various handcrafts were commercialized within the community at low prices. Money stayed in the community and the local economic indicators were further increased as surplus products, particularly meat, which was sold in the big cities as sanitation requirements were fulfilled and new investments took place.

Results of the interviews with the local settlers, who carried out the experiments, were summarized and edited in a video, which is available upon request. Translated transcripts of video excerpts are given below. In all the areas, farmers who conducted the experiments to the end were unanimous in recognizing the advantages of rock fertilizers in respect to conventional chemical fertilizer:

\footnotetext{
"My plantation was a beauty, I got 40 bags of corn, whereas I could hardly get 25 bags before" (2000).

"My family and I could see results. The land where we used the material became much more fertile throughout all these years. We were very happy to participate on this research. It showed that there are other ways to crop food without polluting rivers and the soil. Now we are very happy on continuing this research and I can already see results in the agroforest system we established in the property" (2005).
}

Nascimento Borges de Mendonça (Area 19)

"We only used this chemical stuff because we had no option. What we want is to lead a healthy life. I had no faith in the land, but today I am proud of what we got" (2000).

\section{Manoel Nunes do Prado (Area 129)}

"I very much like this material that comes from the stones. My joint rice and manioc plantation was much greener and the plants grew more. In the veranico (a sudden drought period of 3 to 5 weeks in the (wet) summer; little summer) the plants got much greener in the patches where the material was employed. What we want now is a Government help to bring this material, which comes from the land itself, to all of us. Besides being cheaper, it brings better results. Family farmers need this help" (2000).

\section{José Maria (Area 79)}

"I liked this stuff. My plantation got much prettier and faultless. Before, when the veranico arrived, the leaves turned yellow right away. Now the soil keeps the moisture for much longer, helping the plants. Besides it is cheaper and it has other advantages".

\section{José Pacheco (Area 21)}

\section{CONCLUSIONS}

Rock fertilizer or stonemeal was promptly accepted by farmers because of its simple concept and visible results, leading to positive results and simple assumptions, and also because it is an economically accessible and ecologically lighter practice in terms of the energy demanded, in contrast to conventional agriculture, which has been evolving in a direction that takes it further away from the basic rules of interaction between human beings and the physical environment. On the other hand, it is very easy to obtain rocks or materials derived from them, with adequate composition to be used as fertilizers, since Brazilian territory is geologically diversified. This indicates how easy it is to reproduce this project throughout the country. Furthermore, when one considers the cost of conventional agricultural inputs (many of them imported), the variety of potential useful rocks implies more savings and many benefits. An additional advantage is the incentive to the production of organic compost within the same properties using rock powder as mineral and organic fertilization methods are jointly encouraged. This may reduce the volume of organic residues and the problems created by them at property level, on account of their inadequate disposal.

The major implicit goal of the entire stonemilling project was to demonstrate, with techno- 
logical arguments, that agricultural activity has a major role on the construction of a new model of social development. Project results, both in terms of productivity gains and in terms of the speedy acceptance of the stone-milling technology by family farmers (whose land is their major passport to citizenship), have shown that there are pathways and strategies capable of changing the prevailing patterns of natural resource use. However, the most important lesson learned during the project was the demonstration that the production of healthier and cheaper food is a two-way road. On the one hand, the new technology guarantees productivity levels equivalent to those achieved by conventional agriculture (which is cut off from the basic precepts of harmony between humans and nature), on the other hand, it stimulates the social organization of family farmers. In most farmers opinion, the use of rock powder can be an effective strategy for assuring survival and economic, social and environmental viability of poor farmers, guaranteeing that this marginalized category will continue existing. Successful crops attest the legitimacy of this technology and reinforce proposals made for sustainable development of developing countries such as Brazil. From a strictly technical point of view, during the Project, it became evident that the joint use of rock powder and organic composting was double effective because it accelerates the availability of nutrients, and reduces the volume of rejects (garbage) in properties. Finally, it was noticed that the conflicts, problems and social, economic and environmental consequences of the prevailing agricultural model in Brazil and in other important agricultural countries, point towards a crisis of values and interests, with unpredictable consequences. It can be said that the confrontation between the conventional production model and a more alternative one is a glaring proof of the need for a paradigm shift.

Stonemeal was promptly accepted by farmers because of its positive results and simple assumptions, and also because it is an economically accessible and ecologically lighter practice in terms of energy demanded, in contrast to conventional agri- culture, which has been evolving in a direction that takes it further away from the basic rules of interaction between human beings and the physical environment. On the other hand, it is very easy to obtain rocks or materials derived from them, with adequate composition to be used as fertilizers, because Brazilian territory is geologically diversified. This indicates how easy it is to reproduce this project throughout the country. Furthermore, when one considers the cost of conventional agricultural inputs (many of them imported), the variety of potential useful rocks implies more savings and many benefits. An additional advantage is the incentive to the production of organic compost within the same properties using rock powder, as mineral and organic fertilization methods are jointly encouraged. This may reduce the volume of organic residues and the problems created by them at property level, on account of their inadequate disposal.

Success achieved in several parts of the country demonstrated that the availability of alternative technologies for the production of food has implications that reach far beyond those of a clean technology. Farmers, who use rock powder, have begun to discuss the impacts caused by modern agriculture, as well as ways to change a model that does not include them and does not account for long-term environmental damage. Thus, project results demonstrate that the proposed model of fertilization may contribute to the challenge of reinventing a sustainable future in all its dimensions - ecological, economic, human, ethical, moral, cultural and human and not only a mere adjustment made to the limited rationality of modern development.

\section{RESUMO}

Durante a segunda metade do século 20, a introdução de novas tecnologias agrícolas viabilizou a revolução na produção de alimentos, mas este fato causou também uma profunda deterioriazação na relação dos homens com o ambiente natural. Nos países tropicais, especialmente aqueles em desenvolvimento, os recordes de safras foram acompanhados de êxodo rural, devastação e erosão dos 
solos. A pesquisa sobre o uso da técnica de Rochagem aqui descrita pretende ser uma alternativa tecnológica ambientalmente correta e socialmente responsável para os problemas mencionados. A técnica de Rochagem está baseada no rejuvenescimento e conservação de solos por meio da adição de pós de determinados tipos de rochas enriquecidas em fósforo, cálcio, magnésio, potássio e micronutrientes. A pesquisa foi desenvolvida segundo os pressupostos interdisciplinares e foi conduzida em meio aos agricultores familiares de um assentamento rural localizado no Estado de Minas Gerais, Brasil. Os principais resultados demonstraram que essa tecnologia é uma alternativa de baixo custo e extremamente simples para fertilizar ou recuperar solos degradados, que pode conduzir a sustentabilidade e, também, produções compatíveis de forma que os agricultores possam permanecer em seus lotes. Os resultados da pesquisa mostram que o uso da Rochagem apresenta vantagens econômicas, ambientais e produtivas significativas, em culturas de milho, arroz, mandioca, cana-de-açúcar, e hortifrutigranjeiros em comparação à adubação convencional. A fertilização da terra pela própria terra segue os ensinamentos da natureza (processos naturais), mantendo os níveis de produção com sustentabilidade e preservação dos solos.

Palavras-chave: rochagem, nutrientes, agricultura familiar.

\section{REFERENCES}

Agenda 21. 1992. Agricultura Sustentável. MMA.

CAmpanhola C. 1995. Gestão Ambiental e Crescimento Econômico: In: CONTRIBUição PARA UM Novo Modelo de Desenvolvimento. Centro de Estudos Regionais. CER/UFG. GO, p. 37-57.

Gibson AS, THOMPSON RN, LEONARdos OH, Dickin AP AND MictChell JG. 1995. The late creataceous impact of the Trindade Mantle Plume: evidence from large-volume, mafic, potassic volcanism in SE Brazil. J Petrol 36: 189-229.

Guimarães D. 1955. Contribuição aos estudo dos Tufos da mata da Corda. Instituto de Tecnologia Industrial, Minas Gerais, Brasil, 31 p.

Ilchenko W And Guimarães D. 1953. Sobre a utilização agrícola dos sienitos nefelínicos do Planalto de Poços de Caldas. MG Inst Tecn Avulso 15, 16 p.
Leonardos OH And MeYer HO. 1991. A Geology of Western Minas Gerais. In: LEONARdos, $\mathrm{OH}-$ Field Guindebook. $5^{\text {th }}$ Intern. Kimberlite Conference, Araxá. CPRM, Special Publ 3/91: 17-24.

LeONARdos OH AND Theodoro SCH. 1999. Fertilizing tropical soils for sustaineble development. In: Formoso MLL AND CERRI CC. Proceedings International Workshop on Tropical Soils Rio de Janeiro. Academia Brasileira de Ciências, p. 143153.

Leonardos OH, Fyfe WS ANd Kronberg BI. 1976. Rochagem: O método de aumento da fertilidade em solos lixiviados e arenosos. Anais 29 Congresso Brasileiro de Geologia Belo Horizonte, MG, Brasil, p. 137-145.

Leonardos OH, Fyfe WS AND Kronberg BI. 1987. The Use of Ground Rocks in Laterite Systems: an Improvement to the Use of Conventional Soluble Fertilizers. Chemical Geology 60: 361-370.

LeONARdos OH, TheOdoro SCH AND AsSAD ML. 2000. Remineralization for sustainable agriculture: A tropical perspective from a Brazilian viewpoint. In: Nutrient CyCling in Agroecosystms. Formerly Fertilizer Research 56: 3-9.

Moraes LC, Seer HJ And Kattar SG. 1988. Aspectos Petroquímicos das Rochas vulcânicas alcalinas Cretácicas da Porção Meridional da Bacia Sanfranciscana. Anais $1^{\circ}$ Congresso Brasileiro de Geoquímica, Porto Alegre, RS, Brasil, p. 315-318.

Theodoro SMCH AND LEONARdos OH. 2004. The use of rocks for agriculture in Brazil. CD-ROM $1^{\text {th }}$ International Conference on Rocks for Crops. Brasília, Brazil.

Theodoro SMCH, LeOnardos OH AND PEREIRA MAP. 2000a. Agriculture and environment conflict relationships in Brazilian agrarian reform settlements. $5^{\text {th }}$ International Symposium on Environmental Geotechnology and Global Sustainable Development/BH/MG - CD-ROM, Abstract Book, 16 p.

ThEOdoro SMCH, LEONARDos OH AND DubOIS AM. 2000b. Stonemeal composting: a combined environment-friendly fertilizer technology for degraded areas I Seminário sobre conflitos e uso sustentável dos recursos Naturais, CD-ROM Brasília.

VAN STRAATEN P. 2002. Rocks for crops: Agrominerals of sub-Saharan Africa. ICRAF, 338 p. 